\title{
Retrieving Online Language Learning Resources: Classification and Quality
}

\author{
Zita Krajeso*, Ulrike Frimmel
}

Centre for Translation Studies, University of Vienna, Austria

Copyright $\bigcirc 2017$ by authors, all rights reserved. Authors agree that this article remains permanently open access under the terms of the Creative Commons Attribution License 4.0 International License

\begin{abstract}
Foreign language teachers and learners use digital repositories frequently to find appropriate activities for their teaching and learning activities. The question is: How can content providers support them in finding exactly what they need and in retrieving high quality resources? This question has been discussed in the literature and in the context of research projects. The answers are a taxonomy of searching mechanism and quality criteria of online resources from the methodologic point of view. Correspondingly, this paper introduces a classification of online resources according to the four skills (speaking, writing, reading, listening/watching) and two language use types (grammar, vocabulary), representing the changing paradigm of foreign language teaching and learning. Further the paper identifies quality criteria for designing online learning materials with regard to content, methodology, technic and design. Finally, the findings are illustrated by an example of a learning scenario.
\end{abstract}

Keywords E-Learning, Classification, Quality Criteria, OER, Foreign Language Learning

\section{Introduction}

Recent technological advancement provides challenges for language training institutes and for the education sector as a whole. At EU level, studies show that only $30 \%$ of learners, and even more importantly, only $30 \%$ of teachers can be regarded as digitally competent (see 2013 Communication on OpenupEducation). There is also a lack of high-quality open education repositories designed for language teaching and learning where users could find best practices.

In addition, recent research shows that language learners and teachers would be more inclined to use the world wide web to find appropriate resources for their language learning and teaching activities if they were not discouraged by the huge quantity of materials to select from. According to recent studies, they seek high quality resources and efficient ways for searching and finding materials (accessible within three clicks) from different training backgrounds (classification by subject, topics and level). If we don't want these target groups to get lost in cyberspace, it is crucial to provide adequate support to them and shorten the route to accessible information [20].

\section{Classification Theory}

In this context, the design of teaching and learning activities includes four components: environment, teacher, learner, and activity (including materials/resources). Resource-based learning is a view which gives prominence to the role of resources in the teaching and learning process.

The classification theory of such activities determine different factors playing a role in their design and implementation: age of the learner, teaching approach, topic, form of cooperation, type of the activities, task, assessment, equipment, technical and other pre-requisites, etc. $[16,27,35]$.

Further classifications exist from the technical point of view [12, 32, 38, 39], categorizing on-line activities: virtual classrooms, Hot Potatoes, WebQests, etc.

The classification theory lacks the user involvement and though remains to be the domain of experts rather than users. When users look for an activity for their specific goal, they want to find resources as quickly as possible, probably within three clicks $[8,30]$.

Considering the practice, it can be stated that practitioners search by activity type, topic and level, as these three factors seem to be the most informative and decisive. The rest of the factors build an additional information category (called advanced search) - but they are not a core for the first searching mechanism.

For a better understanding, these three key factors are described in the following paragraph. The most recently and commonly used guideline which describes the achievement levels of foreign language competence is the Common European Framework of Reference for Languages (CEFRL), containing six levels: A1, A2, B1, B2, C1 and $\mathrm{C} 2$. The 
required topics depend, if applicable, on the institutional purpose (curricula, training programme), the goal of the whole class and/or also each and every individual; and can reach from everyday life themes to complex special issues.

The last category, activity type, is much more demanding as the concept of language teaching and learning has changed radically during the last years. Whereas in former days, it was mainly characterized by written grammar and translation exercises, nowadays more skill-oriented activities are prevalent $[2,9,18,31]$. In the next chapter a complex classification of learning activities will be proposed.

\section{Classification of Learning Activities}

According to the "new" paradigm of language teaching / learning activities, exercises and tasks - independent from the language - can be classified as follows [see also

$$
\begin{aligned}
& \text { 14,15,annex I.]: } \\
& \text { - Skills } \\
& \text { - Active skills } \\
& \text { - Speaking } \\
& \text { - Writing } \\
& \text { - Passive skills } \\
& \text { - Reading } \\
& \text { - Listening and watching } \\
& \text { - Language use } \\
& \text { - } \text { Grammar } \\
& \text { - Vocabulary }
\end{aligned}
$$

When teaching / learning a foreign language, it is essential to foster all four skills mentioned above (speaking, writing, reading, listening and watching). For this purpose, it is important to subdivide these rubrics into pre-, during- and post-activities. Young \& Hofer \& Harris [41] explicitly suggest this subdivision only for the passive skill of reading and the active skill of writing. However, this sub-classification makes sense for all four skills.

According to the paradigm transformation in theory, language use activities (grammar and vocabulary) should be embedded in the activities of the skills. Here they build a separate element - as users are used to search materials with keywords grammar and vocabulary. Anyway they should be linked to the specific skill they refer to, and in a later stage, they could be completely integrated to the used skill.

The skills are subdivided into pre-, during- and post-activities (see also annex I. Language learning classification). At the beginning of a learning scenario, knowledge should always be activated or generated in some way, e.g., by brainstorming, researching, etc. This means that learners can activate their prior knowledge or research a new topic before they start with the during-activity. Also information on the educational purposes and objectives should be part of the pre-activity, which helps learners in terms of focus and comprehension [41]. During-activities deal with new learning insights in a specific field of language learning. After the during-activity, a post-activity can involve a knowledge/competence deepening task (mainly active skills activities, e.g., text production), a reflection sequence on the during-activity, e.g., learners can discuss what has been dealt with in the during-activity with their peers, share content with other learners, perform their finished work in class, etc. Also the evaluation of work and the assessment of goals' achievement can be a post-activity [41].

\subsection{Speaking}

As already discussed, the active skill of speaking can be subdivided into pre-, during- and post-speaking activities. After knowledge has been activated in the pre-speaking activity, according to Young \& Hofer \& Harris [41], the following oral performance activity types can be classified:

- Speaking / speech - individual students produce oral language in a variety of contexts, e.g., a book talk, a recitation, an interview, storytelling, etc.

- Performance / production - students participate in a collaborative production, e.g., a dialogue, a dramatic sculpture, etc.

- Furthermore, the following categories can be added to the rubric of during-speaking activities [cf. 5]:

- Discussing literary texts, culture and other topics

- Game tasks with different levels of complexity

- Instruction tasks

- Story telling

While the categories speaking / speech and performance / production can be regarded as during-speaking-activities, the category evaluating or critiquing speech, performance or production has to be classified as a post-speaking-activity as students reflect on what has been performed in the during-speaking activity.

\subsection{Writing}

As already mentioned, the active skill of writing can be subdivided into pre-, during- and post-writing activities [41]. The following activities can be classified as pre-writing activities:

- Brainstorming or listing - students write down ideas as they pop into their minds

- Doodling - students doodle or draw ideas they have in their heads

- Webbing, clustering, semantic mapping - students use webs or clusters in order to create visual representations of brainstorming efforts

- Researching - students explore resources that contain background information related to the topic they are going to write about

Apart from the subdivision pre-writing activities, Young \& Hofer \& Harris [41] mention the category organizing ideas for writing activities. However, these should also be regarded as pre-writing activities as generating knowledge takes place. The following sub-categories are mentioned: 
- Sequencing, outlining, storyboarding - students organize their ideas for writing by creating sequences, outlines or storyboards

- Higher-order webbing or clustering - students organize their ideas for writing by creating higher-order webs or clusters in which there are subsections focusing on different characteristics or categories related to the larger topic

- Choosing form or genre - students organize ideas for writing further by deciding which genre and format they are going to pursue

- Identifying the purpose and the audience - students further organize their ideas by identifying a purpose and a target audience

Young \& Hofer \& Harris [41] also regard (guided) freewriting as a pre-writing activity, but this should be classified as a during-writing activity [4]. Further during-writing activities are the following:

- $\quad$ Drafting - students begin to compose a draft of writing based on their pre-writing activities and ideas for organizing writing; during writing, they redraft and rewrite based on feedback from others and new ideas

- Conferencing - students conference (in person or online, through audio or video) with each other (with or without a teacher) to share writing and provide focused feedback for one another

- $\quad$ Revising - students revise the content of their writing based on feedback from their peers and their instructor, as well as their own ideas

- $\quad$ Editing - students edit their papers to address language conventions appropriate to the context of the piece of writing based on feedback from their peers, their instructor and their own knowledge of accurate mechanics, usage, grammar, and spelling

- Writing fiction - students engage in various writing activities, including fiction (e.g., short stories, graphic fiction, fan fiction, etc.)

- Writing nonfiction - students engage in various writing activities, including nonfiction (e.g., autobiography, diary, essay, news writing, letter writing, persuasive writing, etc.)

- Writing other forms of text - students engage in various writing activities including other forms of text (e.g., academic notes, poetry, screenplay, storyboard, multimodal, multigenre, multimedia, web-based text, participatory media, comic creation, texting, etc.)

- Note taking - students engage in note-taking by copying their teachers' notes from some type of display tool (i.e., chalkboard, projector, etc.) and note taking by creating their own metacognitive reflections in response to texts ${ }^{1}$

In addition, Stevick [37] mentions establishing coherence as during-writing activity.

1 Young \& Hofer \& Harris [41] regard note taking as reading activity, but as it activates the skill writing, it must be mentioned here.
According to Bohn [4], during-writing activities can be classified as follows:

- $\quad$ Reproductive writing - the text read or heard is written down without any changes

- Reproductive-productive writing - the text read or heard has to be understood and changed according to a certain intention

- $\quad$ Productive writing - a text is created according to a certain intention that has been chosen by the student or given by the teacher

Another way to subdivide during-writing activities is the following [4]:

- Guided writing - the writing process is related to a text that has been read or heard (e.g. a dictation, a summary, etc.)

- $\quad$ Free writing - the writing process is not related to a text that has been read or heard

Furthermore, the following post-writing activities can be distinguished, which allow students to share their polished writing with an audience $[37,41]$ :

- Presenting relevant information

- $\quad$ Sharing - students share their finished pieces of writing with a smaller audience

- $\quad$ Publishing - students publish their finished pieces of writing in order to share processed writing with a larger audience

- Performing - students engage in performing their finished writing in order to share it with a specific audience.

\subsection{Reading}

As already discussed, activities focusing on the passive skill of reading can be subdivided into pre-reading activities, during-reading activities and post-reading activities. According to Young \& Hofer \& Harris [41], the following pre-reading activities can be distinguished:

- Activating knowledge - students need to make connections with the reading they have to complete; by activating or generating prior knowledge and experience, students are able to frontload meaning and forge connections with their reading

- Making predictions - as a means of drawing upon existing knowledge and generating new connections with a text, students try to make predictions about texts they are going to read

After the pre-reading activity has been completed, the following during-reading activities can be carried out [11, 24]:

- $\quad$ Selective reading - students understand certain pieces of information

- Global reading - students understand the general idea of a text

- $\quad$ Detailed reading - students understand details of a text 
- Orientating reading - students search and find a specific piece of information

- Aesthetic reading - entertainment and pleasure are important

- Content-oriented reading - students focus on understanding the content

- Analytical reading - students concentrate on a certain detail of the text

- Authentic reading - within a certain period of time, students read a text attentively and repeatedly; thus, a significant progress in the understanding of a text is achieved

Furthermore, the following during-reading activities can be distinguished [41]:

- Directed or guided reading - students are provided specific directions and guidance with a particular text that might range from setting a specific purpose for reading (e.g. to determine the reliability of the narrator) to a directed reading-thinking activity or a detailed guided reading roadmap (i.e., slow down here, skim this, reread here and take notes, skip this section, etc.)

- Sustained silent reading - students read to themselves silently for a required amount of time on a regular basis during school (selections here may vary from student choice to required reading)

- Independent reading - students create individual reading plans that involve reading chosen texts outside of school

- Rereading - students read a selected text several times for increased comprehension

- Dramatic reading / reader's theatre - students participate in and observe dramatic readings of text in order to enhance interest, motivation and comprehension

- $\quad$ Literature reading - students read texts associated with literary study (e.g., novels, short stories, poetry, plays, graphic novels)

- Literature study - students engage in the study of a piece of literature together simultaneously

- Literature circles or book clubs - students in a class are organized in small groups and read multiple books at the same time; selections can vary based on interest, ability, theme, content focus, etc.

- Nonfiction reading - students read texts associated with nonfiction (e.g., essays, news writing, autobiography or memoir, biography, instructional writing, diary, etc.)

- Reading other forms of text - students read other forms of texts, e.g. advertising, speech, screenplay, storyboard, web-based text, e-mail, text messaging, participatory media (blogs, wikis, social networking, etc.), multimodal texts, multigenre texts, comics, etc.

- Consulting resources - students explore and consult resources that might help them writing in some meaningful way (e.g., content, research, format, etc.) ${ }^{2}$
Young \& Hofer \& Harris [41] also regard the following activities as during-reading activities, but these activities should be seen as post-reading activities as students reflect on what they have read in their during-reading activity:

- Reading discussions - students discuss a text with their teacher(s), their peers, and possibly authors, community members, parents, etc.

- Descriptive analysis - students engage in activities focused on a descriptive analysis of a text including conducting character analysis, creating character maps, comparison or contrast, creating story maps or pyramids, answering text-related questions, etc.

- Critical analysis or reflection - students engage in activities that focus on a critical analysis including applying literary theory or criticism, identifying multiple points of view, embedded values, propaganda, etc., making inferences, evaluating sources, relevance, credibility, validity, etc.

Furthermore, the following post-reading activities can be distinguished [41]:

- Completing scales - students complete scales and explain their choices in order to enhance their process and better understand texts, including making comparisons, recognizing differences, drawing conclusions, distinguishing between fact and opinion, etc.

- $\quad$ Summarizing - students summarize a text after having read it by distilling it into shorter pieces that represent key ideas, people, events, etc. (e.g. retellings, text reformulation, book reports, etc.)

- Quizzing, testing - students reveal their knowledge and understanding of a text through their responses on quizzes or tests

- Sharing and collaborating - students extend their understanding of a text by sharing and collaborating with others about their reading experience and what they have learned (e.g. book talks, book reviews, etc.)

Discussion - students discuss a text after having read it with their teacher(s), other students, and possibly authors, community members or parents; the format might range from open-ended discussion to more structured examples like Socratic seminars or debates

- Reconstituting or reconsidering a text - students extend the meaning of a text they have read by reconstituting or reconsidering it in different ways (e.g., re-envisioning it from another character's perspective, re-writing the ending, adding to the text, story recycling, etc.)

- Creating text-related artefacts - students demonstrate their understanding of a text by creating various artefacts related to the content of their reading (e.g. literary essay, collage, bulletin board display, web site, movie, etc.)

- In this context, the following categories can also be added [24]: 
- $\quad$ Making comparisons

- $\quad$ Finding information gaps

\subsection{Listening \& Watching}

As already mentioned, activities focusing on the passive skill of listening \& watching can be subdivided into pre-listening activities, during-listening activities and post-listening activities. While pre-listening activities may involve activating or generating knowledge and brainstorming, the following during-listening activities can be distinguished:

- $\quad$ Listening actively - students listen actively and process the information heard in order to retain it, respond to it, act on it or apply it in some way (e.g. listening to and processing information from a lecture, listening to peers in a discussion, listening to multiple points of view, listening to directions or an explanation, listening to an audio-recording, etc.

- Watching or viewing actively - students watch and process visual images (still or moving, silent or audio-enhanced) in order to create memories, learn from them, respond to them, or act on or apply information they have gained from them (e.g. watching or viewing images, exhibits, demonstrations, etc.)

- Multimodal or multimedia interaction - students listen, watch or view, and interact with or participate in (if applicable) multimodal or multimedia texts; they also process the experience they have gained in order to think, learn, respond, react, or apply knowledge or some aspect of their experience in some way (e.g. listening to a podcast and posting a response to it online either as text or as an audio comment, viewing a multimedia blog that includes digital video segments and then posting responses to various parts of the blog either as text or as digital video, viewing or listening to original audio or video recordings and then creating a remix of those recordings that include elements of the original plus elements the student generates on his or her own, etc.) [41].

Besides, the following listening activities exist [36]:

- $\quad$ Selective listening - students perceive certain pieces of information

- Global listening - students understand the general idea

- Detailed listening - students understand details

- Analytical understanding - students understand the speaker's conclusions, motives, intensions, etc.

- Recognizing - segmenting phonemes

- Understanding - students comprehend the global content of the text; they are able to align pictures to the information heard

- Listening / watching passively

After the during-listening activity has been completed, an evaluation of what has been heard [36] in the during-listening activity (e.g., a personal statement) can be carried out as a post-listening activity. This activity allows students to process critically what they have heard in their during-listening activity in order to make sense of it and respond to it.

\subsection{Grammar}

Grammar is one of many focus areas for studying a foreign language. In order to address language on a broader scale and in ways that go beyond just addressing notions of correctness, it is essential to give students opportunities to explore language, use it, compose it, analyse it and develop a better understanding [41]. In order to achieve these goals, the following activities can be carried out:

- Sentence composing - students build sentences by using sentence composing strategies (e.g., sentence combining, sentence imitation, sentence expanding, etc.) - this results in syntactic growth

- Code switching - students practice code switching in oral and written language, thus developing a better understanding of informal and formal speech varieties as well as the contexts in which each is most effective

- Word analysis - students analyse words in various ways, including origins, parts (e.g., roots, affixes, etc.), formations, functions (i.e., parts of speech), etc.

- Sentence analysis - students analyse sentences in various ways, including the identification of patterns and types, syntax and structure, phrases or clauses, effects of punctuation on style and meaning, etc.

- Style / error analysis - students analyse language to be able to distinguish between style and error (e.g. stylistic choices that break conventions vs. errors in language conventions, dialect choices vs. errors in language conventions, error analysis, etc.)

- Semantic analysis - students engage in semantic analysis in various ways to better understand simple and complex meanings in language (e.g., language as a symbol, abstract vs. concrete language, semantic disruptions, euphemism, etc.)

- Mechanics - students develop an understanding of mechanics in the context of language, especially reading and writing, and an ability to apply it (e.g., capitalization, punctuation, etc.)

- Usage - students develop an understanding of language use concerning reading, writing and speaking (e.g., usage varies based on context, purpose, audience, etc.)

Schifko [34] mentions also the following activities according to the learning stages in the field of grammar:

- Implicit learning - students apply a rule without reflecting it and/or are able to decide whether a phrase sticks to a rule or not

- Explicit learning - students are able to explain a rule by using linguistic terminology and/or by using their own words

When teaching a foreign language, difficulties and confusions that traditional grammar exercises often cause have to be avoided - it is essential to teach grammar in a 
communication-oriented way.

\subsection{Vocabulary}

Vocabulary study can have significant effects on writing and communication. For this reason, it is important for students to have opportunities to develop awareness of, engaging in analysis of, and using new vocabularies. In order to achieve these goals, the following activities can be carried out:

- Vocabulary awareness - students engage in activities that allow them to acquire new vocabularies and develop awareness about various features of sets of words, e.g. similar consonant clusters, similar vowel sounds, similar root words, similar origins, words associated with certain themes, etc.; example activities may include sight words (e.g. word lists) and word play (e.g., crossword puzzles, word search, word matching, word lists, etc.)

- Vocabulary analysis - students analyse new and existing vocabularies in order to develop consciousness about core features of it and more sophisticated understandings about it (e.g. semantic maps, word study, word origins, context clues, use, using the dictionary, etc.)

- Vocabulary use - building on awareness and analysis activities, students use new vocabulary in various contexts in order to adapt it further, developing syntactic complexity and fostering semantic growth (e.g. using vocabulary from word lists tied to literary works or other assigned texts, practicing with homonyms, antonyms, and synonyms, word play, etc.

These activities allow learners to move from the acquisition of vocabularies to comprehension and application [41].

\section{Quality Theory}

Classification as such is crucial for the search mechanism, but quality factors determine the long-term successfulness of digital resources on the users' side [10,23]. In the case of OER, these factors relate to input (quality of the structure and potential), implementation (process) and output (outcome) aspects [23]. In this paper we focus on the input quality criteria of OER and summarize the main results of the research in the context of language learning and teaching in order to determine quality characteristics for OER. Although building the basis for high quality scenarios, these criteria catalogue has not been proven as causal for the learning effect yet [19]. More research is needed to confirm and extend the following quality criteria.

By the categorization of OER quality requirements, a user-friendly version is chosen [for a more complex one, see e.g. 13]. These traditional requirements refer to the following four main categories, which may partly overlap each other:

1. Content

2. Methodology
3. Design

4. Technic

In comparison to traditional educational objects, digital resources should have an added value, which justifies the additional effort in design and which should be also transparent for the user [21,32].

\subsection{Content}

Content deals with topics and subtopics and their educational appeals and the context of language learning / teaching. Characteristics of digital resources basically do not differ from traditional ones. The content must be chosen on the basis of:

1. Context (educational, professional or individual context)

2. Target group (its specific conditions, interests, knowledge, etc.)

3. Educational purpose.

Following the literature in the field of language teaching and learning $[6,25,28,40]$, the content display following aspects, here categorized in general characteristics, attitudes and knowledge factors.

\section{General Characteristics}

- Up-to date and/or updatable, but at the same time reusable,

- Authentic,

- Informative,

- Factual correct,

- Understandable, technical terms are explained,

- Clear structured, coherent, complex issues are organized meaningfully and understandably, avoiding redundancies

- The sample of content is transparent and well founded

- Links to background information for deepening knowledge and know-how are available

- Dictionary / glossary / explanations are/may be integrated

\section{Attitudes}

- Including educational appeal, stimulating learners to up-take attitudes

- Motivating, having a relevance for the learner, his/her attention is captured and maintained

- Polarizing meanings, generating tension, which is the basis for "authentic" interaction

- Vivid, including examples, novel, uncertain events and/or sense of humor

- $\quad$ Free from strong or mistakable stereotypes, meanings and positions, obscene and radical illustrations, etc.

\section{Knowledge/Competence}

- Linked to the users' professional (e.g. curriculum, occupation) context, life and experiences, e.g. activate and recall prior knowledge 
- Varied, include more than one perspective of a topic, motivating learners to decision making

- Besides information it includes also know-how (strategic competence) aspects

- Higher/more complex than the learners' knowledge/skills

\subsection{Methodology}

Methodology refers to the didactical principles, teaching and learning theory and praxis, purposes and design of tasks, and takes into account the up-to-date research in the disciplines psychology, sociology, education, linguistics and neurophysiology [1].

In the context of OER, approved methodologic concepts remain valid when ICT (information and communication technology) is implemented as an instrument for a didactically meaningful purpose. The didactic concept is the most crucial aspect for the acceptance and success of the ICT implementation. According to literature [25,28], the methodology is divided into goals, activities and tasks.

\section{Goals}

- Oriented towards the users' context

- Oriented towards the methodological variety

- Learner-centered (oriented towards the learners' interests, abilities, learning progress and other specific conditions)

- Coherent and structured into main purposes and sub-goals

- Represented in a transparent way (purposes and benefits are recognizable) so that the learner is able to develop consciousness for the learning purpose

- The achievement of goals is provable in some way

\section{Activities}

- Clearly structured and coherent

- Oriented towards the methodological purpose and linked to the content

- $\quad$ Divided in pre- during- and post-activities (see chapter Classification of learning activities)

- Foster decision-making, autonomous, critical and life-long learning processes

- Foster varied learning possibilities

- Foster not only individual work, but also interaction and communication if necessary

- $\quad$ Provide feedback, review, information on assessment, to foster the learners' acknowledgment

Tasks

- Varied, fostering the learners' intrinsic motivation

- Different levels of difficulty (at the beginning easy, later more complex)
- The dimension of media competence is taken into account (competence of media critic, usage, design and publishing )

- Clearly structured

- Coherent (e.g. instructions follow nominal or verbal style, formal or informal form), correct terminology and free from failure

- Meaningful for the purpose and the learner

- Praxis and real-life oriented, realistic problem solving, fostering the acquisition of application-oriented knowledge

\subsection{Design}

Design involves all aspects we can sense with our organ of perception: visual and auditory issues (text, graphic, symbolic, color, background, picture, video, sound, etc.). High quality design reflects the following characteristics [13, 28]:

\section{- User-centric}

- Appropriate and didactically meaningful chosen (oriented towards educational purposes, context, learners' specifications and content)

- Functional, logic and focused

- Consistent, coherent and complementary

- Integrated in a learning motivating way

- Ergonomic (e.g. color contrasts are pleasant)

- Aesthetic (attractive to the learners)

- High-quality

- Is in any way harmful to anybody

- The written or oral text is well readable, audible

- Appealing and clear layout

\subsection{Technic}

In this paper the category of technic deals with the pedagogical view of learning systems, their functionalities and possibilities, and does not include implications to hardware, software or engineering issues.

The implementation of LMS (learning management system), media and tools should be oriented towards the methodology: goal, task, content, specification of the learner and the context. In the case of e-learning, the didactical purpose is in the middle of attention, not technic or tools. The rule is: as much technic as necessary and as little as possible. According to the literature [17, 26, 28, 33], the different technical arrangements work immaculately and fast and fulfil the following prerequisites:

- Functionality

- Intuitive usage, the user should feel a certainty by using ICT

- Support (information on different technical possibilities, user guidelines, contact)

- Clear, consistent and user-friendly regarding structure, terminology of the tools and their use (e.g. navigation)

- Continuity regarding learning objects, tools, LMS 
- User-friendly surface (as simple as possible)

- Possibilities of individual, cooperative, synchrony and asynchrony learning/work on content (e.g. groupware)

- Different communication channels (chat, mailing list, video conferencing, news-groups)

- Possibilities for upload, store, edit, reuse and transfer of different learning materials

- Possibilities for learning assessment, automatic documentation of achieved goals

These recommendations are crucial for ensuring quality criteria and simplifying searching mechanism, but how does a high quality learning scenario look like in real-life?

\section{Implementation to Praxis}

For illustration, the resource portal of the British Council (http://learnenglish.britishcouncil.org) has been chosen. The example learning scenario presented in this paper is called "The Fridge". It is about a man who sends a Facebook friendship invitation to a woman who he met in a restaurant. However, before accepting his invitation, she first wants to get to know him better. Therefore, he invites her for dinner to his place and cooks lasagna for her.

This learning scenario involves a pre-, a during- and a post-activity. In the pre-activity, vocabulary that is used in the during-activity, i.e. the film, is dealt with - words have to be matched with definitions. In the during-activity, the student watches a short film (the man who invites a woman for dinner tells the whole story outlined above). It is possible to have a look at the transcript of the film at any time during the whole learning scenario.

In the post-activity, the learner has to put given sentences into the correct order so that they describe the story presented in the film. Afterwards he/she has to indicate if given sentences about the film are true or false. Finally, the recipe of the lasagna the man has cooked is given. There is also a forum where people can discuss the film, the recipe, etc.

This learning scenario was chosen as an example because it illustrates how important it is to offer students a variety of activities, e.g., vocabulary exercise (pre-activity), watching a film (during-activity) and putting sentences in the correct order, true-false-exercise and discussion (post-activity). "The Fridge" also shows how different learning styles and paces can be coped with as students can take as much time as they need for completing the scenario, and moreover, it is possible to have a look at the transcript of the film at any time. This supports self-controlled learning and students' autonomy and may enhance the learning intensity.

Furthermore, this learning scenario is especially suitable for language teaching and learning purposes as learning processes and knowledge construction are focussed on learners have to match words and definitions themselves. In addition it is functional and user-oriented, i.e. the learning scenario presents a useful result - here, the lasagna recipe is given. Furthermore, it fosters personal reflection and interaction - in the discussion forum, students can discuss the film, the recipe, etc.

From the content point of view, this learning scenario is real-life-oriented because a recipe is given that can actually be tried by the learners and because the discussion forum allows users to exchange their experience with the lasagna, the film, etc. Moreover, social activities on Facebook represent the starting point of the during-activity, which are an important part of young people's life. This makes it especially vivid and interesting for them to complete the tasks. The learning scenario "The Fridge" is up-to-date and authentic as it deals with getting to know new friends and adding them on Facebook - this attracts the students' attention. Furthermore, it is informative including background information like an explanation for the term "lasagne" and presents how a lasagna recipe can be tried (representing know-how). Narrating the happenings by talking into the inside of a fridge / to us, makes the monologue of the actor vivid and gives the learning scenario an unexpected plus.

The visual design of the learning scenario is simple and practical. The colours are reduced to grey and green and their shadows have a clean appearance. In addition, they make a good detail contrast (e.g., by defining the content areas and dividing the activities into different sections) and match the websites' main colours. However, the typography especially the font size - could be more consistent, gaining a more professional effect.

The technical realisation of the learning scenario is functional, the site works fast, the navigation bar is simple, it is clear what is clickable. The icons are transparent, understandable and make the activities easy to use. However, according to the postings, some users have difficulties in playing the video, but a link with a description is provided and technical support is given through the LearnEnglish Team. Anyway, the technical support/link should be placed more transparently, perhaps included in the right column - in case of following the two-column layout meaningfully. The answers can be checked at the end of every activity and are also included in the pdf version of the learning scenario.

As far as the use of technologies is concerned in language learning, this example has shown that technology-enhanced materials do have a lot of potential. Anyway it is challenging to design effective online resources for language teaching and learning purposes. Therefore, content providers should take into account the quality catalogue and the classification presented in this paper. Employing the principles offered in the corresponding chapters will help all stakeholders to ensure that their efforts are rewarded, ultimately, with satisfied users.

\section{Conclusions}

Nowadays the Internet is frequently used as a pool of resources to find appropriate material for teaching and 
learning languages. However, users have to be prevented from getting overwhelmed by the mass of resources that can be found in the World Wide Web. It is crucial to support them to find high quality resources and to retrieve easily what they need for their purposes. Accordingly, developments and recommendations on language learning taxonomy that can be used for structuring language teaching and learning resources has been described. In addition, quality criteria for open educational resources have been outlined. In order to illustrate the outcomes of the paper, a real-life learning activity has been introduced.

\section{Annex I. Language Learning Classification}

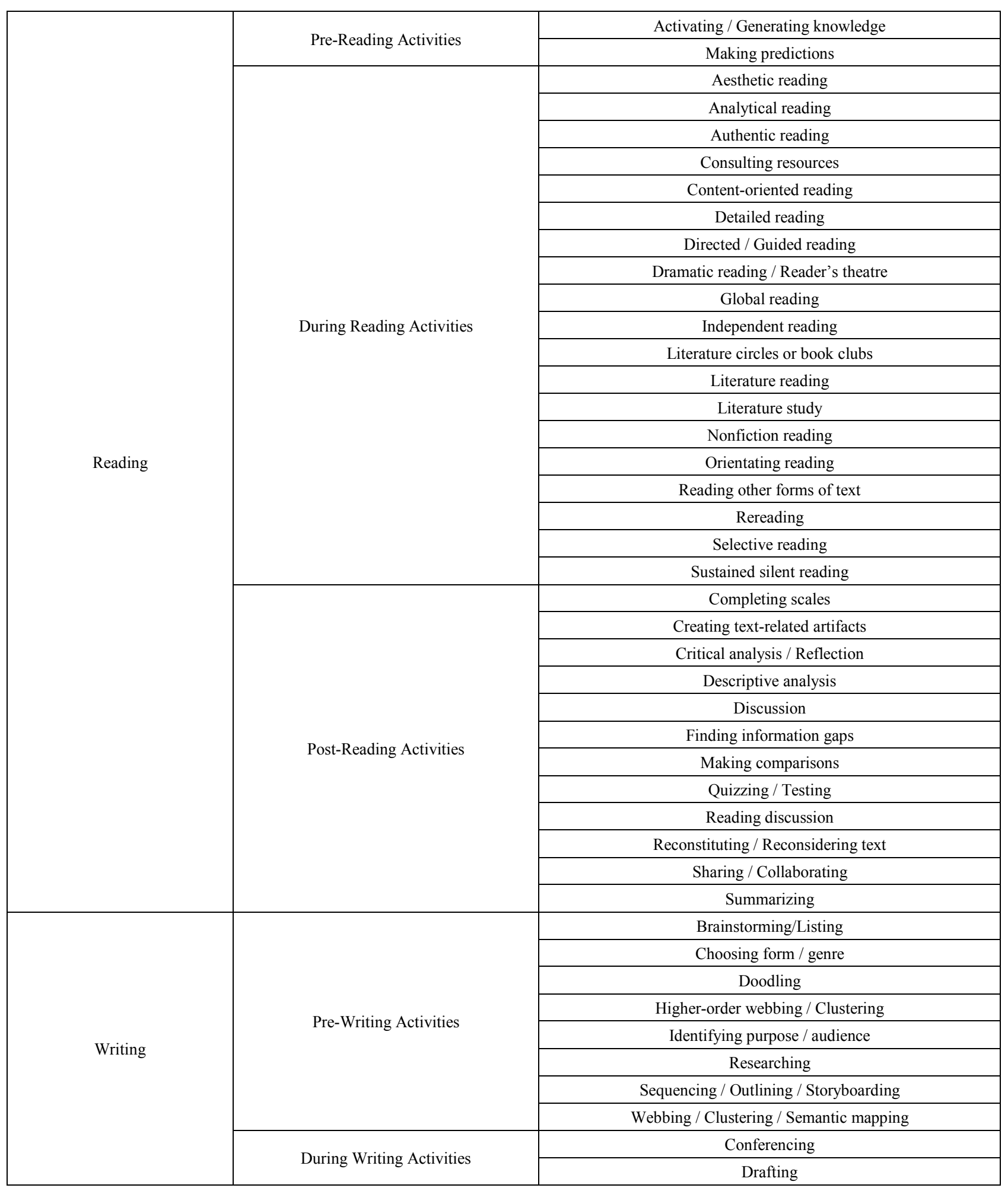




\begin{tabular}{|c|c|c|}
\hline & & Editing \\
\hline & & Establishing a coherence \\
\hline & & Free-writing / Guided free-writing \\
\hline & & Guided writing \\
\hline & & Note Taking \\
\hline & & Productive writing \\
\hline & & Revising \\
\hline & & Reproductive-productive writing \\
\hline & & Reproductive writing \\
\hline & & Writing Fiction \\
\hline & & Writing Nonfiction \\
\hline & & Writing Other Forms of Text \\
\hline & \multirow{4}{*}{ Post-Writing Activities } & Performing \\
\hline & & Presenting relevant information \\
\hline & & Publishing \\
\hline & & Sharing \\
\hline \multirow{8}{*}{ Speaking } & Pre-Speaking activities & Activating knowledge \\
\hline & \multirow{6}{*}{ During Speaking activities } & Discussing literary texts, culture and other topics \\
\hline & & Game tasks with different levels of complexity \\
\hline & & Instruction tasks \\
\hline & & Performance / Production \\
\hline & & Speaking / Speech \\
\hline & & Story telling \\
\hline & Post-Speaking activities & Evaluating / Criticizing Speech / Production \\
\hline \multirow{12}{*}{ Listening / Watching } & \multirow{2}{*}{ Pre-Listening activities } & Activating / Generating Knowledge \\
\hline & & Brainstorming \\
\hline & & Analytical understanding \\
\hline & & Detailed listening \\
\hline & & Global listening \\
\hline & & Listening / Watching actively \\
\hline & During Listening activities & Listening / Watching passively \\
\hline & & Multimodal or multimedia interaction \\
\hline & & Recognizing \\
\hline & & Selective listening \\
\hline & & Understanding \\
\hline & Post-Listening activities & Evaluating \\
\hline & & Code Switching \\
\hline & & Explicit learning \\
\hline & & Implicit learning \\
\hline & & Mechanics \\
\hline & Grommon & Semantic Analysis \\
\hline & urammar & Sentence Analysis \\
\hline & & Sentence Composing \\
\hline & & Style / Error Analysis \\
\hline & & Usage \\
\hline & & Word Analysis \\
\hline & & Vocabulary Analysis \\
\hline & Vocabulary & Vocabulary Awareness \\
\hline & & Vocabulary Use \\
\hline
\end{tabular}




\section{REFERENCES}

[1] K.H. Arnold, B. Koch-Priewe, S. Lin-Klitzing. Allgemeine Didaktik, Fachdidaktik und Unterrichtsqualität. K.H. Arnold (Eds.), Unterrichtsqualität und Fachdidaktik, 19-49, Bad Heilbrunn, Klinkhardt, 2007.

[2] K.R. Bausch, Ch. Herbert, H.J. Krumm. Handbuch Fremdsprachenunterricht, Tübingen, Francke, 2003.

[3] E. Bloh. Qualität und Evaluation metzbasierten Lehrens und Lernens. B. Lehmann, E. Bloh (Eds.), Online-Pädagogik, Band 4, Qualität und Evaluation, 7-143, Baltmannsweiler, Schneider, 2010.

[4] R. Bohn. Schriftliche Sprachproduktion. G. Helbig, L. Götze, G. Henrici, H.J. Krumm, (Eds.), Deutsch als Fremdsprache, Ein internationales Handbuch, Berlin, de Gruyter, 921-931, 2001.

[5] H. Bolte. Fremde Zungenschläge - Handlungsräume für die Entwicklung mündlicher Kommunikationsfertigkeiten im Fremdsprachenunterricht, Fremdsprache Deutsch, Vol.14, 4-19, 1996.

[6] E. Bratengeyer, A. Bubenzer, J. Jäger, G. Schwed. eLearning Qualitäts-Evaluationstool, Books on Demand, 2015.

[7] B. Combes, R. Valli. The future of learning objects in educational settings, Learning objects: Applications, implications \& future directions, Santa Rosa, CA, Informing Science Press, 423-461, 2007.

[8] K. Clements, Z. Krajcso, M. Moises, A. Lazonder, H. Pirkkalainen. A socially-driven content repository - Open Discovery Space Portal. Proceedings The European Conference on Technology in the Classroom, Brighton, 2013.

[9] DESI-Konsortium. Unterricht und Kompetenzerwerb in Deutsch und Englisch, Weinheim, Beltz, 2008.

[10] U.D. Ehlers. Qualität beim E-Learning: Der Lernende als Grundkategorie bei der Qualitätssicherung, MedienPädagogik, Online-Zeitschrift für Theorie und Praxis der Medienbildung, 1/2002. Lernsoftware Qualitätsmaßstäbe, Angebot, Nutzung und Evaluation, 2002.

[11] S. Ehlers. Entwicklung von Lesekompetenz in der Fremdsprache, Babylonia 3+4, 31-38, 2006.

[12] U. Felix.. Schritt halten mit dem Web: Die Aufgabe lösen, Online available from http://www.gfl-journal.de/1-2002/felix.html

[13] C. Ch. Frey. Kostenfreie Online-Lehrmittel. Eine kritische Qualitätsanalyse, Bad Heilbrunn, Verlag Julius Klinkhardt, 2015.

[14] U. Frimmel, Z. Krajcso. Classification of online resources in the field of language teaching, Proceedings The European Conference on Language Learning Brighton, 2013.

[15] U. Frimmel, Z. Krajcso. Online Language Teaching Resources: Classification, Implementation and Guide, Proceedings The Fourth International Conference on e-Learning (eLearning-2013), Belgrade, 2013.

[16] U. Häussermann, H.E. Piepho. Aufgaben-Handbuch Deutsch als Fremdsprache: Abriß einer Aufgaben- und Übungstypologie, München, Iudicium, 1996.
[17] S. Hemsing. Simply the best 10 Erfolgsfaktoren für gutes E-Learning, Hamburger eLearning-Magazin, Was ist gutes eLearning? Qualität in Lehr-/Lernszenarien mit digitalen Medien, 2015.

[18] E. Hinkel. Current Perspectives on Teaching the Four Skills, TESOL Quarterly Vol.40/1, 109-131, 2006.

[19] M. Kerres, A. Preußler. Mediendidaktik. F. Gross, D.M. Meister, U. Sander (Eds.). Medienpädagogik - ein Uberblick, Weinheim, Beltz Juventa, 2015.

[20] Z. Krajcso. Classification and Quality Criteria for Open Educational Resources in the field of Foreign Language Learning. Journal of Language and Cultural Education Vol.4/1, 68-84, 2016.

[21] C. Kreidl. Akzeptanz und Nutzung von E-Learning Elementen an Hochschulen, Münster, Waxmann, 2011.

[22] D. Laurillard, M. Oliver, B. Wasson, U. Hoppe. Implementing technology-enhanced learning. N. Balacheff, S. Ludvigsen, T. De Jong, A. Lazonder, S. Barnes (Eds.), Technology-enhanced learning: Principles and products, Springer: New York, 289-307, 2009.

[23] B. Lehmann, E. Bloh. Online-Pädagogik. Band 4: Qualität und Evaluation, Baltmannsweiler, Schneider, 2010.

[24] F.J. Meißner. Lesen, Lesekompetenz, Leseförderung in fremden Sprachen, Lesen, Lesekompetenz, Leseförderung, Akten des GMF-Sprachentages Aachen 2011. GiF:on (Giessener Fremdsprachendidaktik online), E. Klein, FJ. Meißner, T. Prokopowicz (Eds.) Online available from http://geb.uni-giessen.de/geb/volltexte/2013/9525/pdf/GiFon _1.pdf, 2013.

[25] H. Meyer. Was ist guter Unterricht? Berlin, Cornelsen, 2004.

[26] B. Mikuszeit, U. Szudra. Qualitätsanforderungen für didaktische Multimediaprodukte. In: B. Mikuszeit, U. Szudra (Eds.). Multimedia und ethische Bildung. E-Learning - Ethik - Blended Learning, Frankfurt/Main, Peter Lang, 195-222, 2009.

[27] G. Neuner, M. Krüger, U. Grewer. Übungstypologie zum kommunikativen Deutschunterricht, München, Langenscheidt, 1981.

[28] M. Niehoff. Fremdsprachenlernen mit Multimedia. Anforderungen aus Sicht der NutzerInnen. Eine qualitative Untersuchung zum selbstorganisierten Lernen. Frankfurt/Main, Peter Lang, 2003.

[29] A. Pinter. Teaching Young Language Learners. Oxford Handbooks for Language Teachers, Oxford, University Press, 2006.

[30] H. Pirkkalainen, J. Jokinen, J. Pawlowski, T. Richter. Overcoming Cultural Distance in Social OER Environments. S. Zvacek, M. Restivo, J. Uhomoibhi, M. Helfert (Eds.), CSEDU 2014, Proceedings of the 6th International Conference on Computer Supported Education, Vol.1, SCITEPRESS Science and Technology Publications, 15-24, 2014.

[31] J. Richards, W. Renandy. Methodology in Language Teaching: An Anthology of Current Practice, Cambridge, University Press, 2002.

[32] D. Rösler, S. Ulrich. Vorüberlegungen zu einer Übungs- und 
Aufgabentypologie für internetgestütztes

Fremdsprachenlernen. M. Legutke, D. Rösler (Eds), Fremdsprachenlernen mit digitalen Medien. Tübingen, Gunter Narr Verlag, 2003.

[33] G. Salmon. E-tivities. Der Schlüssel zu aktivem Online-Lernen. Zürich, orell füssli, 2004.

[34] M. Schifko. DaF-Grammatik - Reader 2: Vermittlung \& tasks. Unpublished reader, 2006.

[35] Ch. Segermann. Typologie des fremdsprachlichen Übens. Dortmunder Konzepte zur Fremdsprachendidaktik Band 1, Bochum, Brockmeyer, 1994.

[36] G. Solmecke. Das Hörverstehen und seine Schulung im Fremdsprachenunterricht. Der fremdsprachliche Unterricht Englisch Vol.4+5, 4-10, 2003.

[37] E. Stevick. Memory, meaning and method, Newbury House, Rowley, Mass, 1976.
[38] A. Tiutenko, G. Koller. Prinzipien einer sprachübergreifenden Typologie von Lern- und Testaufgaben für elektronische Sprachlehrwerke. F. Klippel, G. Koller, A. Polleti (Eds), Fremdsprachenlernen online, Münster, Waxmann, 2007.

[39] A. Westhofen. Typologie von WWW-Übungsmaterialien im Bereich Deutsch als Fremdsprache, Fachtagung lnternet im Unterricht Deutsch als Fremdsprache. Online available from: http://www.edition-deutsch.de/tipps/vortrag-westhofen-uebu ngstypologie.pdf, 2001.

[40] G. Westhoff. Über die Lernwirksamkeit von Sprachlernaufgaben am Beispiel von "WebQuests". Fremdsprache Deutsch Vol.38, 12-18, 2008.

[41] C.A. Young, M. Hofer, J. Harris. Secondary English language arts learning activity types, Online available from: http://activitytypes.wmwikis.net/file/view/SecEngLangArtsL earningATs-Feb2011.pdf, 2011. 